\title{
SPIRITUAL-HUMANISME HASAN ASKARI DAN DIALOG INTERRELIGI DI INDONESIA
}

\author{
Aulia Kamal \\ Universitas Islam Negeri Sumatera Utara (UINSU) Medan \\ auliakamal2014@gmail.com
}

\begin{abstract}
Abstrak
Paper inimembahasspiritual-humanisme dariHasanAskari sebagai dialog interreligi alternatif. Data dikumpulkan melalui kajian pustaka, dan melalui content analysisrisetini menunjukkan bahwa;Pertama; kritik Askari atas dialog interreligi berangkat dari pengamatannya bahwa sampai saat ini dialog belum mencapai inti dari dialog, yakni kesadaran spiritual.Dialog interreligi harusnya bukan mendialogkan identitas kolektif yang memang tidak akan pernah bisa dihilangkan. Sebaliknya dialog harus dicapai melalui; (1)mengalami realitas jiwayang melampaui batas identitas; (2) melalui pertemuan antar pribadi sebagai sesama manusia dan konsekuensi dari kesatuan spiritual.Kedua,pada prakteknya dialog interreligi di Indonesia masih cenderung menekankan pada konsensus antar identitas, bukan menyadarkan kesatuan jiwa sebagai sesama manusia, sebagai sesama warga negara. Ketiga, ide Askari ini lebih relevan dalam konstruksi dialog di Indonesia dengan memper-timbangkan fakta pluralitas yang berbasis pada: (1) identitaskeagamaan dan kebudayaan. (2) pengalaman spiritual masyarakat Indonesia.Dua hal ini dapat menjadi landasan untuk mengembang-kan spiritual-humanisme sebagai dialog interreligi alternatif di indonesia.
\end{abstract}

Kata kunci: Dialog interreligi, Hasan Askari, Spiritual-Humanisme

\section{Abstract}

This paper discusses spiritual-humanism initiated by Hasan Askari as an alternative interreligious dialogue. Data was collected through literature review and through Content Analysis, this research shows some findings; First; Askari's criticism of interreligious dialogue departs from his observation, that until now dialogue has not yet reached the core of dialogue, which is spiritual awareness. Interreligious dialogue should not be to dialogue with collective identities whose can never be eliminated. Instead, dialogue must be achieved through; (1) experiencing the reality of the soulthat transcends the limits of identity; (2) interpersonal encounters as human beings and as the consequences of spiritual unity. Second, in practice, interreligious dialogue in Indonesia generally tends to emphasize the consensus of identities, not to awaken the unity of the soul as bumans, as citizens. Third, Askari's idea is more relevant in the construction of dialogue in Indonesia by considering the fact of plurality in Indonesia based on: (1) religious and cultural identity; (2) spiritual experiences of Indonesian society. These, can be the basis for developing spiritual-bumanism as a model ofdialogue in Indonesia.

Keywords: Hasan Askari, Interreligious Dialogue, Spiritual-Humanism. 


\section{Pendahuluan}

Dialogantar agamaadalah fokus utamadari model pendekatanantar agama (interreligious approach) yang merupakansalah satu dari tigabentukpendekatan agama dalam masyarakat agamis; monoreligi (monoreligious), multireligi (multi-religious) dan antaragama (interreligious) seperti yang telah dikenal dalam studi agama khususnya dalam kaitannya dengan kajian model pendidikan keagamaan di Indonesia sebagaimana kategori yang dibicarakan oleh Carl Sterkens dalam Interreligious Learning: The Problem of Interreligious Dialogue in Primary Education(2001).

Paper inisecara khusus membahas lebih lanjut tentangdialogyangdimaksudkandalam pendekataninterreligious karena model pendekatan inilah yang sampai hari ini masih dianggap sebagai satu-satunya model terbaik untuk menumbuhkan kerukunan hidup beragama dan menghilangkan konflik-konflik keagamaan dalam masyarakat yang majemuk seperti di Indonesia.Namun di luar ituterdapat pula ide alternatif dari Hasan Askari yang mencoba menggagas sebuah konsep yang menurutnya lebih tepat untuk diaplikasikan dalam mengelola kemajemukan masyarakat, yakni spiritual-humanisme.

Prof. Syed Hasan Askari (1932-2008) atau lebih dikenal dengan nama Hasan Askari merupakan salah satu Sosiolog dan tokoh muslim-syi'ah asal India yang dikenal sebagai penganjur dialog antar agama, spiritualinterreligi dan pemikiran-pemikirannya sangat mempengaruhi kajian atas masyarakat multireligi di Barat. Askari juga tercatat memberi kuliah di berbagai universitas dan negara, baik India, Lebanon, Jerman, Belanda, Inggris dan Amerika. Pemikirannya dapat dilacak dalam beberapa karya besarnyadi antaranya; Foundations of Applied Sociology (1968), A Study of Religion in a Multireligious Society (1977), atau kumpulan esainya Inter-Religion (1977), kumpulan esai keduanya Spiritual Quest: An Inter Religious Dimension(1991), Towards a Spiritual Humanism(1991).The Experience of Religious Diversity(1984) bersama John Hick, Alone to Alone: From Awareness to Vision(1991), Seers \& Sages(1991) bersama David Bowen, atau Solomons Ring: The Life and Teachings of a Sufi Master (1997).

Ketajaman pemikiran dan pengaruhnya telah disejajarkan dengan delapan tokoh pemikir muslim lainnya di antaranya seperti Fazlur Rahman dan Abul Kalam oleh Kenneth Cage dalam The Pen and the Faith (1985). Askari sangat aktif dalam aktivitas akademik dan konferensi internasional khususnya terkait dialog lintas agama atau masyarakat agama. Perjumpaan dan jaringan relasinya yang luas dengan banyak tokoh dari berbagai kalangan dan kelompok agamasebagian di antaranya seperti W.C. Smith, Michael Fitzgerald, Lamin Saneh, John B. Taylor, Mohammed Arkoun, Harun Nasution, M.M. Ayoub,Mohammed Talbi, Talmon, Greenberg, K. Sviraman, T.N.Hanh, diakuinya turut mengkonstruksi perkem-bangan pemikirannya terkait masyarakat multireligi (Woly, 2008: 168). 
Gagasan spiritual-humanisme Hasan Askarisangat menarikdanpenting untukdikajimengingatpembahasandi dalamnya sangat dekat terkait denganapa yang seringkalidipelajari dalam studi agama pada umumnya, kerukunan umat beragama. Dialoginterreligiini sebenarnya adalah modeldialog yangdidasarkan padapemahamannilainilaipluralistikdalam agama, tetapitidak cukup sampai di situ, HasanAskarimenempatkandialoginterreligidalam modelyang ia sebutsebagai spiritualhumanisme.

Paper iniakanmenunjukkanideHasanAskaridanjuga menunjukkanargumenyang digunakannyauntuk menemukan apakah gagasan mengenai spiritual-humanisme dapat menjadi model yang paling ideal dalam mengelola keragaman agama di Indonesia dan patut dipertimbangkan dalam dialogantaragama. Untuk itu, pertama sekali, paper ini akan mengeksplorasi apa yang disebut dialog antaragama (interreligious dialogue), kemudian menguraikan spiritual-humanisme, selanjutnya dilakukan analisis deskriptif atas kedua tawaran tersebut dan diakhiri dengan sebuah kesimpulan.

\section{Memahami Pendekatan Dialog Interreligi (Interreligious Dialogue)}

Istilah dialog berasal dari bahasa Greek 'dialogus' yang berarti 'dwi-cakap' atau percakapan antara dua orang atau lebih, dialog juga berarti tulisan dalam bentuk percakapan, pembicaraan atau diskusi di antara orang-orang yang berbeda pendapat (Daya, 2004: 20).Ketika term dialog ini dipadukan dengan kata 'antar agama'maka tidak hanya pada pengertian komunikasi terbuka terhadap sesama umat beragama saja, namun juga pada pengertian interaksi sosial yang kompleks dengan melibatkan semua elemen-elemen keagamaan dalam ruang sosial.

Oleh sebab itu terkadang istilah dialog lintas iman atau dialog iman juga seringkali dipakai untuk tujuan dan maksud yang sama. Agaknya perlu dipahami pula bahwa istilah dialog ini lahir bersamaan dengan menguatnya isu-isu konflik di berbagai belahan dunia yang melibatkan agama di dalamnya. Sebenarnya interreligi merupakan salah satu term yang digunakan untuk membedakan tiga model pendekatan dalam studi masyarakat agama sebagaimana telah disebutkan di awal, yaitu monoreligious, multireligious dan interreligious(Sterkens, 2001: 47).

Menurut Ahmad Munjid (2014), model-model tersebut adalah sama-sama merupakan model studi yang efektif selama ditempatkan dalam konteks yang berbeda. Pertama, pendekatan monoreligi(monoreligious approach) yang merupakan pendekatan paling efektif untuk tujuan internalisasi kualitas iman.Sehingga pendekatan ini umumnya dilakukan di pesantren atau seminari dengan latar belakang pendidikanuntuk satu agama yang tunggal. 
Kedua, pendekatan multireligi(multireligiousapproach) yang dimaksudkan untuk mendapatkan pemahaman yang informatif-deskriptif tentang agama lain dalam masyarakat majemuk. Pendekatan kedua ini tampak misalnya dalam tulisan-tulisan atau pengajaran mengenai suatu agama yang ditulis atau diajarkan oleh penganut agama tertentu sekedar untuk menampilkan informasi deskriptif terkait agama lainnya tanpa bersentuhan langsung.

Ketiga, pendekatan yang terakhir adalah pendekatan interreligi (interreligious approach).Perbedaannya yang paling mencolok dengan pendekatan multireligi adalah, jika pada pendekatan multireligicenderung menekankan pada pengajaran agama-agama yang bersifat deskriptif, informatif dan objektif tentang doktrin, ritual, dan sejarah agama tertentu.Maka dalam pendekatan interreligiini interaksi yang dibangun semakin bergerak lebih jauh dengan menekankan pada aspek dialog keagamaan (Munjid, 2014).

Sekilas tampaknya tidak ada perbedaan yang terlalu signifikan antara multireligi dengan interreligi.Sebab sebenarnya simplifikasi paling umum yang berlaku atas masyarakat agama adalah bahwa konsentrasi dari masyarakat agama memang terbagi ke dalam monoreligimultireligi, atau homogen-heterogen.Sementara interreligi merupakan bentuk konsekuensi dari keberadaan masyarakat multireligi. Model monoreligi cenderung pada kehidupan beragama yang homogen dalam ruang sosial yang eksklusif. Sementara dalam model multireligi, beberapa agama bertemu dalam satu masyarakat heterogen yang masih memiliki batas-batas komunikasi dengan memberikan dan menerima informasi dari satu agama ke agama lain.Dalam relasi ini tidak ada interaksi secara terbuka antar agama dalam posisi yang setara.

Namun kemudian dalam model interreligi, komunikasi memang berjalan sangat aktif dan interaksi menjadi sangat terbuka dengan memfokuskan pada dialog antar agama. Dalam hal ini Burhanuddin Daya menggambarkan dialog interreligi sebagai pertemuan hati dan pikiran untuk menghilangkan agresifitas diantara berbagai agama.Sebagai jalan komunikasi, pendekatannya bukan menonjolkan klaim kebenaran, namun berbentuk kerjasama dalam proyek-proyek bersama, bersifat partnership tanpa ikatan dan agenda tersembunyi, saling mendengarkan dengan penuh keterbukaan, bukan bermaksud untuk sinkretisasi, membebaskan dari ikatan sistem yang tertutup, memberi suatu visi mengenai dimensi spiritual yang lebih luas sesuai dengan kehidupan spiritual yang lain (Daya, 2004: 20-22).

Hans Kung, tokoh dialog antar agama yang terkenal dengan jargonnya 'tidak ada perdamaian dunia tanpa perdamaian agama' merupakan tokoh paling giat mengkampanyekan dialog antar agama, ia berkata:

“...kita memerlukan dialog dengan tanggung jawab saling menjelaskan dan sadar bahwa tidak satu pun dari kita memiliki kebenaran 'yang telah tercipta', tetapi semua menuju pada kebenaran 'yang lebih mulia' ...Kebenaran tidak dapat berbeda dalam 
agama-agama yang berbeda, kebenaran hanya satu. Melewati semua pertentangan, kita harus mencari apa yang dapat saling melengkapi; dari semua hal yang eksklusif, kita harus mencari apa yang inklusif.” (Kung, dkk., 2009: 17).

Pernyataan tersebut dengan jelas mereduksi dialog sebagai jalan untuk menjelaskan kepada semua agama bahwa kebenaran adalah satu.Tidak melekat pada suatu agama secara otomatis bahkan sejak agama itu muncul, tetapi agamalah yang berusaha mendatangi kebenaran itu.Sehingga bagi Hans Kung, dialog harus bertujuan mempertemukan agamaagama dengan sesuatu yang inklusif yang dapat saling melengkapi diantara agama-agama tersebut.

Menurut Burhanuddin Daya (2004: 22-24), ada beberapa alasan kenapa dialog interreligi menjadi wacana penting, antara lain; secara fitrah manusia adalah bomoreligious. Kemudian, kebebasan beragama adalah hak paling mendasar bagi manusia dan menuntut hak untuk melakukan praktek-praktek keagamaan.Di samping adanya kesan permusuhan antara Barat dan Timur yang sudah terbentuk berabad-abad, adanya keyakinan tentang kesatuan asasi umat manusia dan persahabatan, juga fakta terbentuknya masyarakat pluralis di era globalisasi dan terakhir, karena alasan adanya konflik yang melibatkan agama di seluruh dunia.

Dari pandangan tersebut, tujuan yang ingin dicapai dari dialog interreligi adalah kerukunan sosial, membudayakan keterbukaan dan saling menghormati melalui kesadaran plural, tujuan paling penting adalah menciptakan perdamaian. Nilai pluralitas inilah yang dianggap sebagai modal sekaligus jalan ideal untuk menciptakan harmoni dalam perbedaan tradisi keagamaan. Mengenai interreligi dan pluralitas ini, Carl Sterkens menulis:

"This plurality is seen as an opportunity for mutual enrichment. The interreligious model not only observes and describes the plurality, but also deals with it constructively. It seeks to express the uniqueness of each religious tradition, and at the same time to evaluate the plurality of religions positively in a nondiscriminatory way. Even more cogently: without contact with other approaches, without a plurality of religious concepts or without the presence of other religions, a religious tradition cannot survive because it is continually confronted with new problems. It is through dialogue with other traditions that it becomes conscious of its own fallibility, imperfections and uncritical assumptions, and is able to correct them.'(Sterkens, 2001: 63).

\section{Praktek dan Efektivitas Dialog Interreligi}

Bentuk-bentuk dialog interreligi sudah berkembang dalam berbagai bentuk tergantung orientasi dan kondisi yang dihadapi, seperti dialog kehidupan, dialog perbuatan, dialog kerukunan, dialog sharing pengalaman agama, dialog kerja sosial, dialog doa bersama, dialog teologis, interfaith dialogue, dialog terbuka, dan sebagainya. Namun dialog interreligi lebih 
banyak diwujudkan dalam bentuk pertemuan-pertemuan antar pemimpin atau tokoh agamaagama sebagai pertemuan seremonial yang formal belaka.

Di tingkat internasional, dialog mulai muncul pada tahun 1965 yang dikembangkan oleh Dewan Gereja-Gereja se-Dunia (DGD) di Inggris yang merancang rumusan tentang dialog. DGD inilah yang bekerja meneruskan dialog interreligi di tingkat internasional sehingga semakin berkembang sampai sekarang. Tahun 1970 dialog secara resmi di Beirut dihadiri 28 utusan Kristen, lima utusan Hindu, empat dari Buddha, dan lima orang dari Islam dengan menghasilkan beberapa rekomendasi.Bahwa perlu meneruskan dialog pada tingkat lokal, dialog akan terus diperluas, dialog harus dipertimbangkan untuk masuk dalam kurikulum pendidikan, terakhir, perlu adanya diskusi-diskusi personal, antar organisasi yang berhubungan dengan dialog (Daya, 2004: 24-27).

Di Indonesia hal yang sama juga dilakukan oleh Lembaga Pengkajian Kerukunan Umat Beragama (LPKUB), Badan Musyawarah Antar Umat Beragama, Lembaga Pengkajian Kerukunan Antar Umat Beragama, Dialog Antar Iman (DIAN) dan lain-lainnya. Kesemuanya adalah bentuk usaha yang mengagendakan dialog antar agama sebagai fokus utama dan dianggap efektif untuk mengantisipasi konflik agama di Indonesia.

Jika dilihat lebih lanjut, secara teoritis efektifitas dari dialog interreligi tidak dapat dilepaskan dari usaha banyak lembaga dan komunitas yang mendukung ide-ide dialog sebagai solusi konflik yang ideal. Leonard Swidler (1983),misalnya, menyarankan 10 prinsip dasar dialog yang disebutnya The Dialogue Decalogueprinsip-prinsip ini meliputi:

1. Dialog bertujuan untuk mempelajari perubahan dan perkembangan persepsi realitas dan meresponnya.

2. Dialog harus merupakan proyek antara dua pihak.

3. Dialog harus diikuti dengan kejujuran.

4. Masing-masing agama yang berdialog harus mendefinisikan diri sendiri.

5. Peserta dialog tidak tergesa-gesa terhadap hal yang tidak disetujuinya.

6. Dialog hanya bisa dilakukan dalam posisi yang setara.

7. Dialog dilakukan atas dasar saling percaya.

8. Orang yang mengikuti dialog harus kritis terhadap agama partner dan agamanya sendiri.

9. Setiap peserta harus mencoba mengalami pengalaman agama dari partnernya secara bersama-sama.

10. Peserta tidak boleh membandingkan idealismenya dengan praktek keagamaan partnernya (Swidler, 1983: 1-4). 
Prinsip-prinsip dialog yang diusulkan Swidler ini kemudian diadopsi oleh banyak organisasi sebagai karakter dialog interreligi di seluruh dunia, seperti Global Interfaiths Dialogue Movement (GIDM), International Association for Religious Freedom (IARF), World Congress of Faiths (WCF), The Temple of Understanding, atau dalam bentuk pertemuan-pertemuan Kristen-Islam, konferensi-konferensi, seminar, kongres, jurnal-jurnal dan studi-studi keagamaan yang dimasukkan dalam institusi pendidikan, semua usaha tersebut berakhir pada terbentuknya World's Parliament di Chicago tahun 1893. Dari berbagai pertemuan internasional sampai organisasi tingkat regional dan lokal inilah dialog interreligi dianggap telah menjadi solusi efektif untuk konflik agama di dunia.

Secara konseptual, di tingkat internasional dialog cenderung dilakukan untuk mengkonstruksikan konsep dialog yang ideal yang dapat diterima masyarakat global. Selain itu dialog tersebut dirancang guna membicarakan mengenai isu-isu global yang berhadapan dengan agama serta masalah konflik-konflik agama yang merupakan fokus utama dari dialog. Sementara di tingkat nasional atau lokal seperti di Indonesia, dialog ini cenderung dijadikan sebagai media penyelesaian konflik juga sebagai agen sosialisasi kerukunan antar agama.

Artinya, dialog tersebut lebih menonjolkan sisi keragamaan identitas pihak yang terlibat untuk kemudian dimusyawarahkan dan dicapai suatu konsensus bersama atas perbedaan persepsi atau obyek yang didialogkan. Paling tidak kecenderungan ini telah menunjukkan bahwa model dialog yang dipahami secara umum di Indonesia selalu berbasis pada identitas material-ideologis. Pendekatan dialog semacam ini dipandang masih efektif untuk menyelesaikan persoalan konflik sosial keagamaan di masyarakat.

Anggapan tersebut dapat dilihat dari dialog interreligi sebagai pendekatan resolusi konflik sosial bernuansa agama yang melibatkan sikap inklusif, koperatif dan akomodatif. Namun pendekatan ini terjebak pada soal identitas ideologis pihak berdialog yang seringkali ikut ditonjolkan dalam dialog. Hal ini terntu saja ambiguitis mengingat tujuan dari dialog adalah mencari kesamaan persepsi atas suatu persoalan sehingga dicapai suatu solusi dengan upaya meminimalkan perbedaan-perbedaan dari pihak yang terlibat.

Kecenderungan semacam ini bisa ditemukan dalam komunitas dialog di beberapa wilayah di Indonesia yang heterogen seperti diLembaga Rumah Bentang di Kalimantan Tengah, Pela di Maluku, Subak Madewi di Bali dan Marga di Tapanuli Selatan (Daya, 2004: 234). Kabupaten Poso di Sulawesi Tengah, Kecamatan Astanaanyar di Bandung (Ahmad dan Suhanah, 2009: 162-181). Atau pada kegiatan-kegiatan dialog kerukunan umat beragama yang rutin dilaksanakan oleh Forum Kerukunan Umat Beragama (FKUB) Kementerian Agama 
Republik Indonesia di tingkat atas sampai bawah. Model dialog semacam inilah yang dikritik oleh Hasan Askari sebagaimana akan ditunjukkan pada bagian selanjutnya.

\section{Spiritual-Humanisme Hasan Askari}

Dialog antar agama meskipun kelihatannya sudah diterima sebagai gagasan yang ideal yang mempresentasikan agama sebagai media dialog bagi permasalahan global.Namun isu tersebut masih dilihat sebagai bagian eksoteris saja sementara aspek esoterisnya belum terumuskan dengan baik. Dialog interreligi tidak hanya menuntut dukungan dari teologi transendensi tetapi juga antropologi spiritual.Hal ini melibatkan keyakinan filosofis tentang jiwa manusia sebagai prinsip universal, yang itu sendiri merupakan sumber dari keragaman dan kesatuan manusia dan mengandung ekspresi konkret dalam kehidupan sosial.

Hasan Askari (2004) menilai keragaman agama dapat disatukan dengan menjadikan jiwa sebagai titik temu dari dialog interreligious, jiwa itu banyak tetapi pada saat yang sama adalah satu, oleh karena itu, untuk mengalami kebenaran tentang diri sendiri dan tentang yang lain adalah dengan mengalami realitas jiwa yang melampaui batas identitas.

Dalam buku Perjumpaan di Serambi Iman (2008), Askari merumuskan empat hal yang penting untuk memahami hubungan antara interreligi dengan spiritual-humanisme. Pertama, interreligi adalah dilema esensial dalam tradisi agama. Kedua, interreligi adalah bagian penting dari sejarah semua agama. Ketiga, interreligi adalah wujud interaksi agama yang universal menjadi agama interkultural. Keempat, interreligi adalah bentuk daya saling tarik-menarik antar agama (Woly, 2008: 199-202).

Menurut Askari, dialog interreligi yang dipraktekkan sekarang tampaknya telah gagal dalam semua bidang karena dua hal. Pertama, belum disertai dengan artikulasi yang jelas dari visi antropologis dari satu spiritual kemanusiaan. Kedua, terjadi kesenjangan antara dialog interreligi dan masyarakat. Oleh karena itu tidak ada gunanya menghubungkan harapan yang dipromosikan dalam dialog interreligi dan situasi sosial di seluruh dunia yang telah berubah menjadi hal yang disebutnya sebagai ethno-sentrisme dan obskurantisme relijius (Askari, 06/01/20014).

Askari(2004) menawarkan beberapa langkah untuk mengembangkan pendekatan spiritual-humanisme dalam dialog. Pertama, pada tingkat intelektual akademik langkah ini dimulai dengan menghidupkan kembali wacana klasik tentang jiwa dan menumbuhkan teologi transendensi sebagai bagian integral spiritualitas multireligi. Kedua, pada tingkat ideologis dan pedagogis, perlu pembongkaran dan penanaman pandangan spiritual-humanisme untuk menggantikan eksklusivitas dalam beragama(exclusivereligionism)dan sekularisme dengan 
spiritual-humanisme. Ketiga, pada tingkat kenabian, perlu adanya kritik untuk menghadapi semua kekuatan yang memperbudak dan melumpuhkan jiwa manusia.

Penjelasan yang diberikan oleh Askari nampaknya terlalu panjang dalam hal ini.Namun secara ringkas, bagi Askari apa yang disebutnya sebagai spiritualitas adalah kumpulan nilai-nilai universal dari semua agama seperti hikmah, kearifan, cinta, perdamaian dan nilai-nilai positif lainnya yang diajarkan dalam semua agama.

Namun jika dilihat pada cara-cara agama bertindak, pada dasarnya dipengaruhi oleh bagaimana agama mendefinisikan dirinya, identitas dan sebuah prinsip penting yaitu klaim kebenaran. Sehingga ketika dibandingkan dengan nilai-nilai spiritualitas tersebut yang dimiliki oleh setiap agama, identitas eksklusif ini memiliki pengaruh lebih besar karena identitas lebih ditampilkan ketika berhadapan dengan agama yang lain.Inilah yang cenderung menyebabkan konflik menurut Hasan Askari. Terkait dengan ini ia berkata dalam bukunya:

"Hal-hal yang kita saksikan dari agama lain seperti panggilan untuk ibadah, bacaan kitab suci, atau lainnya tentang tradisi tersebut dikondisikan oleh pengalaman Kita mengenai tradisi tersebut, perasaan tentang identitas terbuka, dan tertutup dan finalitas sikap kita terhadap klaim teologis agama." (Askari, 2003: 171).

Askari berargumen bahwa kenyataannya dalam penyamaan antara persepsi, identitas dan finalitas klaim, yang dipahami bukanlah pribadi (person), tetapi jenis dari identitas. Misalnya, ketika memperkenalkan seseorang yang beragama Kristen kepada muslim, maka muslim akan melihat orang itu sebagai Kristen. Sebagai identitas komunalnya (collective identity), bukan sebagai pribadi, begitu pula sebaliknya. Pertemuan spiritual adalah pertemuan antara dua pribadi dan bukan antara dua tipe identitas. Sekalipun seseorang itu benar menurut ciricirinya atau tindakannya, citra yang diproyeksikan terhadap orang tersebut selalu saja tentang identitasnya, yang menjadikan pertemuan itu mengabaikan dia sebagai pribadi.

Lebih lanjut, dalam spiritual-humanisme terdapat tiga postulat utama. Pertama, kemanusiaan adalah satu kesatuan ekologis organik sebagai bentuk dari kehidupan planet (Humanity is one organic ecological whole as a planetary form of life). Kedua,kemanusiaan adalah satu kesatuan politis ekonomis (Humanity is one economic political whole). Ketiga,kemanusiaan adalah satu kesatuan spiritual yang tidak terpisahkan (Humanity is one indivisible spiritual whole) (Spiritual Humanism, 04/04/2012).

Melalui tiga postulat itu Askari memulai gagasan spiritual-humanismenya dalam dialog interreligi. Sebab menurut Askari, langkah pertama menghubungkan spiritualitas dan realitas adalah dengan menerima orang lain sebagai pribadi.Sebagai sesama manusia yang berada di satu bumi yang sama, bukan identitas kelompoknya (dalam hal ini adalah agama).Dimulai dengan memahami kesatuan internal bahwa manusia berasal dari tuhan, memahami 
indivisibilitas manusia sebagai satu pribadi, dan wujud spiritual manusia yang berdasarkan dua hal itu (Askari, 2003: 172-173).

\section{Relevansi Spiritual-Humanisme untuk Kerukunan di Indonesia}

Dari pemahaman ini, maka faktor yang menutupi kesatuan esensial manusia sebagai pribadi yang satu adalah identitas kolektif seperti Kristen, Yahudi, Hindu dan lainnya. Juga bentuk fisik seperti ras, bahasa, bangsa, budaya, atau lainya. Sebenarnya agama telah memiliki jalan untuk membawa manusia kepada pemahaman ini dengan jalan-jalan esoteris-metafisis. Seperti tasawuf dalam Islam, meditasi dalam Hindu-Buddha, atau asketisme dalam Kristen.Bagi Askari, tidak ada jalan lain kecuali menerima orang lain sebagai identitasnya dan menerimanya juga sebagai bagian dari pribadi yang tunggal. Dengan begitu nilai-nilai spiritual yang disebutnya seperti cinta, damai, hormat, atau lainnya dapat diwujudkan secara spontan, dan karena itu pula keberagaman agama merupakan fakta yang wajar sebagai jalan mencari transedensi tuhan.

Askari mengatakan bahwa pencarian bukan berarti pertukaran keimanan kepada keimanan lainnya.Tetapi pergerakan dari kesadaran eksoteris kepada kesadaran esoteris.Manusia sebagai seorang pencari (the seeker) harus memahami keberadaan realitas tertinggi yang lepas dari agama-agama manapun, sehingga kita harus menerima keberagaman agama (Askari, 2003: 181). Selain itu jiwa tidak memiliki perbedaan apa-apa, dengan demikian maka kesadaran spiritual dapat menjadi modal dalam masyarakat multireligi.

Jelas bahwa Askari memahami dialog agama dengan pendekatan ini, bukan dengan modal pluralitas tetapi melalui spiritualitas. Dialog adalah even spiritual, sehingga dialog seharusnya tidak terkontrol, tidak diprediksi, dan agendanya tidak terbatas. Dialog bukan sebatas pertemuan, tetapi hubungan dan pengalaman interreligi. Istilah spirituality dalam 'sharing in spirituality tidak selalu berarti bersama-sama dalam mengikuti suatu ibadah agama lain. Tetapi berarti berusaha memahami nilai-nilai ibadah, penyerahan diri, dan meditasi yang terdapat dalam tradisi dan praktek agama mitra dialog (Schumann, 2008: 35).

Dalam hal ini Askari memandang bahwa sesuatu yang personal dapat dialami dalam antar personal yang menjadi bandingan spiritual bagi interreligi.Karena dialog interreligi yang baik bukan pertemuan antara sistem-sistem agama, tetapi antara pribadi dengan pribadi (Schumann, 2008: 209). Pendekatan spiritual semacam ini dinilai lebih efektif oleh Askari mengingat jiwa merupakan kesadaran paling universal dan dapat diterima oleh semua masyarakat karena agama sendiri dibangun atas dasar dari kesadaran spiritual.

Pada tataran praktis, kasus dan praktek yang menggunakan pendekatan spiritualhumanisme ini sepertinya nampak pada gerakan-gerakan yang mengkampanyekan 
perdamaian.Melalui sekolah-sekolah singkat, pelatihan-pelatihan, atau kegiatan yang semacamnya yang mengunggulkan konsep spiritual dari berbagai agama sebagai dasar pengenalan pluralitas.Di antaranya misalnya: Yayasan Anand Ashram, Koperasi Global Anand Krishna, Yayasan Pendidikan Integral Satu Bumi, One Earth College of Higher Learning, atau One Earth, One Sky, One Humankind Retreat Center. Beberapa nama ini berada dalam sebuah yayasan yang didirikan oleh Anand Krishna yang orientasinya mengkampanyekan nilai-nilai spiritual dari semua agama sebagai hal yang penting untuk menumbuhkan pemahaman spiritualitas yang universal, bebas dari perbedaan-perbedaan eksterior (oneearthcollege.com, 18/12/2014).

Dialog interreligi sebagaimana yang dikampanyekan oleh banyak institusi saat ini lebih banyak menampilkan dialog dalam bentuk yang sangat formal, megah, dari level internasional sampai lokal. Inti dari dialog yang ditawarkan oleh perspektif ini adalah fakta pluralitas dalam masyarakat multireligi. Pendekatan yang demikian menjadikan dialog interreligi hanya mampu memotivasi kelompok identitas yang didialogkan sebatas pada upaya menahan diri untuk tidak menonjolkan identitas masing-masing tanpa menyentuh inti dari dialog yang sebenarnya.

Selain itu tingkat efektifitas dialog interreligi cenderung didorong oleh penerimaan fakta pluralitas sebagai modal dialog oleh banyak institusi bahwa pendekatan pluralitas adalah solusi yang efektif dan menjanjikan perdamaian bagi konflik agama. Asumsinya, masyarakat yang telah memahami pluralitas akan pula memahami nilai-nilai integritas yang kuat dalam diri dan lingkungannya. Namun seperti telah ditunjukkan pendekatan ini kurang efektif untuk menanamkan kesadaran atas hak-hak orang lain atas nama manusia penghuni bumi yang sama.

Tawaran dari Hasan Askari bahwa dialog interreligi seharusnya dilakukan dengan modal spiritualitas-humanisme sebaliknya melihat bahwa upaya dialog harus mencapai inti dari dialog. Ia yakin bahwa dialog dengan bentuk-bentuk yang telah banyak dilakukan saat ini belum mencapai tingkat kesadaran dialog yang sebenarnya kecuali dialog dengan pendekatan spiritual. Ia melihat dialog seharusnya adalah pertemuan antar pribadi dengan pribadi sebagai manusia dengan alasan kesatuan spiritual, bukan dengan mendialogkan identitas-identitas kolektif yang perbedaannya tidak akan pernah bisa dihilangkan.

Askari berpendapat, pada dasarnya manusia memiliki kesatuan internal seperti keyakinan semua agama bahwa manusia berasal dari tuhan, indivisibilitas manusia sebagai satu pribadi, dan manusia memiliki jiwa yang sama tanpa identitas yang bertentangan. Kesadaran atas kesatuan asal inilah yang harus dikampanyekan dan dikembangkan terus ke berbagai lapisan masyarakat sebagai jalan dialog yang sesungguhnya.

\section{Penutup}


Dua sudut pandang ini, dialog interreligi dan spiritual-humanisme sama-sama merefleksikan gagasan yang baik sebagai modal untuk dialog perdamaian.Tetapi ada sedikit perbedaan tingkat efektifitas antara keduanya. Dalam model dialog interreligi dengan pendekatan pluralitas, dialog cenderung dipersepsikan sebagai penyadaran komunal untuk menerima perbedaan-perbedaan identitas dengan alasan perbedaan adalah hal yang alamiah.

Tetapi sekalipun praktek dialog itu lebih luas dan beragam, pada prakteknya dialog lebih banyak diasosiakan dengan pertemuan, konferensi, dan acara-acara seremonial-formal lainnya.Sehingga hanya efektif di kalangan pemimpin-pemimpin keagamaan yang terbatas, tetapi tidak menjangkau semua level dalam masyarakat.Jelas, dialog dengan cara demikian tidak terlalu efektif.Oleh karena itu dalam masyarakat khususnya di Indonesia, pengertian dialog kemudian harusnya lebih diimplementasikan dalam bentuk kerjasama dalam masalah sosial, dalam kampanye kerukunan beragama, dalam menghadapi masalah-masalah bersama.

Melalui dialog spiritual-humanisme seperti yang digagas oleh Hasan Askari, dialog lebih berpotensi untuk mengubah konflik di masyarakat dengan pendekatan antar pribadi.Artinya dialog bukan berbentuk pertemuan-pertemuan megah, yang dihadiri pemimpin-pemimpin keagamaan dalam ruang tertutup.Tetapi interaksi langsung dari masingmasing pribadi dalam masyarakat dengan mengabaikan identitas-identitas kolektif. Masyarakat harus terus didorong untuk menyadari kesetaraannya sebagai sesama manusia yang percaya kepada tuhan. Sebagai makhluk hidup yang sama-sama tinggal di bumi. Sebagai sesama warga negara Indonesia yang sama-sama memiliki hak dan kewajiban di negaranya.

Tetapi kemudian, pendekatan spiritual-humanism ini harus diakui juga sangat beresiko karena sangat dekat dengan sinkretisme.Sebab dengan menonjolkan kesamaan esensial sedemikan rupa, maka hal-hal yang sifatnya eksoteris menjadi tidak penting lagi untuk dipertimbangkan. Atau justru dianggap sebagai faktor penghambat proses perdamaian melalui jalur spiritual yang memang harus menembusi sekat-sekat eksoteris dan harus mengutamakan unsur-unsur esoteris saja.

Inilah satu hal yang dihindari oleh semua agama di dunia, dan akan sukar dihilangkan. Sebab selama ini persoalan sinkretisme juga menjadi bebandalam konsep pluralisme agama yangdikritikdan ditolak. Sehingga melahirkan konsep alternatif yang dikenal sebagai 'pluralisme kewargaan' (civic pluralism) sebagaimana tawaran Zainal Abidin Bagir (2011).Namun begitu, tentu perlu dibangun sikap optimis bahwa dua perspektif ini-dialog interreligi dengan menekankan pluralitas dan dialog spiritual-humanisme yang menekankan pada kesadaran spritual—memiliki titik temu sehingga dapat dikombinasikan. 
Kesadaran pluralitas dan nilai-nilai spiritualitas dapat saling menguatkan dengan jalannya masing-masing.Melalui kesadaranatas pluralitas dialog dibangun untuk menerima perbedaan yang eksis dari luar. Sementara dengan kesadaran spiritualitas masyarakat diajarkan untuk dapat mengembangkan kemampuan menerima keberadaan orang lain sebagai sesama makhluk ciptaan tuhan, sebagai bagian dari alam, sebagai sesama manusia yang hidup di satu planet yang sama, sebagai sesama warga negara Indonesia, dan sebagai bagian dari kehidupan yang perlu dihormati keberadaannya.

\section{Daftar Pustaka}

Askari, H. (2003). Lintas Iman Dialog Spiritual, Yogyakarta: LkiS Yogyakarta.

Askari, H. (2004). "From Interreligious Dialogue to Spiritual Humanism”,Interreligious Insight, (04/01/2004); http://www.interreligiousinsight.org/January2004/Jan04Askari.html\&usg=ALkJrhgMzTkmVyc9d8OpI-B9Of2S5klCA. accested Dec $13^{\text {th }} 2014$.

Askari, H. (2012). Spiritual Humanism, http://spiritualhuman.files.wordpress. com/ 2012/04/ , Accested Dec $18^{\text {th }} 2014$.

Ahmad, H. (2009). "Kerjasama Antarumat Beragam dalam Wujud Kearifan Lokal di Kabupaten Poso" and Suhanah, "Kerjasama Antarumat Beragama di Kecamatan Astanaanyar, Bandung” in Jurnal Harmoni, vol. VIII, No. 30, April-Juni Puslitbang Kehidupan Keagamaan Badan Litbang \& Diklat Departemen Agama RI.

Bagir, Z. A. dkk., (2011).Pluralisme Kewargaan: Arah Baru Politik Keragaman di Indonesia, (Yogyakarta: Center for Religious and Cross-cultural Studies, Universitas Gadjah Mada bekerjasama dengan Penerbit Mizan.

Daya, B. (2004). Agama Dialogis: Merenda Dialektika dan Realita Hubungan Interreligious, Yogyakarta: Mataram-Minang Lintas Budaya.

Sterkens, C. (2001).Interreligious Learning: The Problem of Interreligious Dialogue in Primary Education (Empirical Studies in Theology), Leiden: Brill.

Swidler, L. (1983). The Dialogue Decalogue: Ground Rules for Interreligious

Dialogue. Horizons, 10(2), 348-351. doi:10.1017/S0360966900024087.

Kung, H, Syafaatun A. and Gerardette P. (2009).Jalan Dialog, Yogyakarta: Program Studi Agama dan Lintas Budaya.

Woly, N. J. (2008).Perjumpaan di Serambi Iman, Jakarta: BPK Gunung Mulia.

Shumann, O. H. (2008).Dialog Antar Umat Beragama, Jakarta: BPK Gunung Mulia. 
Munjid, A. (2014).Pengajaran Agama Interreligius, www.kompas.com 06 Januari 2014 cited from http://doabagirajatega.blogspot.com ～/2014/01/pengajaran-agama-interreligius achmad.html. Accested Dec $18^{\text {th }} 2014$. 